\title{
EVALUATION OF THE ENGLISH LANGUAGE TEACHING PROGRAM OF THE FACULTY OF EDUCATION, UNIVERSITY OF BENGHAZI USING THE PEACOCK MODEL: TOWARDS QUALITY EDUCATION
}

\author{
Regilito D. Laurel ${ }^{1 \mathrm{i}}$, \\ Annabelle C. Belting', \\ Ennaji Omran Almansouri ${ }^{3}$ \\ ${ }^{1}$ Assistant Professor, PhD, \\ English Department, \\ Faculty of Education, \\ University of Benghazi, \\ Libya \\ ${ }^{2}$ Lecturer - English, PhD, \\ Department Faculty of Education, \\ University of Benghazi, \\ Libya \\ ${ }^{3} \mathrm{MA}$, Head - English Department, \\ Faculty of Education, \\ University of Benghazi, \\ Libya
}

\begin{abstract}
:
The English Language Teaching (ELT) is a theory and practice of English teaching and learning for the welfare of the non-native students whose language is not English. It is an English language degree in exploring the application of the language development and current practice in teaching and testing. The study aims to identify the aspects of the English Language Teaching (ELT) and how do the aspects of the English Language Teaching (ELT) program should be maintained and improved based on the Peacock's Model and Evaluation. The study employs the quantitative and qualitative descriptive research design and method. The study comprised seventeen (17) alumni of the Faculty of Education, English Department, University of Benghazi, Libya as these participants had experienced the evaluation of the English Language Teaching program to be maintained and to be improved in the Faculty of Education. Purposive sampling is utilized in the study because it is non-probability which is known as judgmental, subjective, and selective sampling. Results show that participants are encouraged to be a reflective teacher when they start teaching and taught to evaluate themselves as a teacher which is vital and important in ELT profession in the Faculty of Education and in English
\end{abstract}

${ }^{i}$ Correspondence: email : regie0407@gmail.com 
as a Foreign Language, show to promote flexibility in using different teaching practices in different situation and classroom management skills in terms of participation, show that there is adequate training and teaching skills and balances of teacher-centered and student-centered learning on its courses in ELT in terms of experimentation, show to avoid overlapping information between different courses and are ready to teach ELT of the program in the university in terms of application, and show that participants are encouraged to reflect on their past experiences as a language learners and are encouraged to be a reflective teacher in their teaching process in terms of cooperation.

Keywords: evaluation of English language teaching, program of English Language Teaching, quality of education, PEACOCK model and evaluation

\section{Introduction}

The English Language Teaching (ELT) is a theory and practice of English teaching and learning for the welfare of the non-native students whose language is not English. It is an English language degree in exploring the application of the language development and current practice in teaching and testing. It gains knowledge and skills to produce and design the materials for language lesson and analytical development and critical skills and thinking. It is a challenge in the Faculty of Education in University of Benghazi to consider as essential in English Language Teaching and learning. It is an interactive method and approach that plays a crucial role in dealing with students (Matkasimova, \& Makhmudov, 2020).

On the other hand, the absence of available records/documents at the University of Benghazi relative to the curriculum innovation in general and in the aspect of the evaluation of English Language Teaching program in particular justifies the significance of this study. The need and benefit of the English Language Teaching (ELT) have upgraded or have changed in the globalized world especially in the English language use or lingua franca. It showcases the ELT creativity, and diverse ways to a successful communication that encounters a multilingual implication for the said module. It provides an insight in the related innovation curriculum and design in the teacher education syllabus. It provides different stages in the process of innovation to ensure sustainable and successful ELT curricular innovation (Galloway, \& Numajiri, 2020).

Moreover, it's true that there are lots of qualitative and effective evaluations of different programs in higher education, however, the researchers of the present study could not find any program evaluation of the English Language Teaching in Benghazi. With regard to the significant role of program evaluation in the improvement of education, the researchers attempted to bring the program under focus to examine its quality and achievement. The technological advances in ELT have affected various areas of students in the manner of their communication, learning, collaboration and course process. The students in the $22^{\text {nd }}$ century must have a critical thinking and functional skills related to the English Language Teaching (ELT) information and technology to 
succeed in their learning perspective since there are issues in learning and language teaching which are essential in building perspective skills in the global modern society. The traditional classroom teaching styles have evolved in the different advent of instruction and teachers are adjusting in the various approaches depending on the needs of the students (Jabbarova, 2020).

Therefore, it is necessary to know whether or not the required objectives are met. Since the graduates of every program are likely to have an overall evaluation of different aspects and factors involved, the present study attempted to examine the extent to which the current program was successful in achieving its goals from the graduates' viewpoints. ELT is a language classroom based-assessment to include the summative and formative assessment method of evaluation. The formative assessment characteristic contains the adaptation of teachers' classes and immediate teachers' feedback while summative assessment and evaluation which is considered as challenging assessment for effectiveness, dependability, standard, safety, and control. It is suitable in any multiple standard and places for the achievement of the judgment on learners and evaluates the whole process of the education effect in the English Language Teaching. It provides assessment and development in the reference and expected language classroom-based teaching and learning (Chen, 2020).

Furthermore, the PEACOCK Model is patterned in the study where the acronym formed with the initial letters of indicators as Participation, Experimentation, Application, Cooperation and Knowledge Model for successfully implementing Comprehensive and Continuous Evaluation. The Peacock Model takes care of the "Learning to Be" and "Learning to Live Together" concept along with the ideas of "Learning to Know" and "Learning to do." Therefore, the model caters to the skills of learners in cognitive, psychomotor \& interpersonal domains. In the proposed paper, an attempt will be taken to explore the nature and scope of the Models introduced in ELT classroom teaching-learning and also the role of teacher in such classroom for the benefit of the learners and achievement of the goal as fixed in the curriculum. It proceeds to present the topic in detail and utilizes the printed materials such as books and journals, and e-resources as mentioned in the work cited. It provides new method and learning process and style. It focuses on learning insight and styles in a broader based formulated for smart educators in building the system in education to deliver faster and better ELT, (Jabari, 2020).

Educational programs are designed to accomplish a set of specific objectives and purposes. To assure that the intended objectives are met, evaluation of the program is an essential step in the whole processes so that people in charge decide to continue or bring about necessary revision in the program where it maintains the purpose of program evaluation to focus the attention on the objective of achievement for the next alternative in decision making. It is a teaching approach and adoption of the widely international context in language integration and language learning. It promotes the educational system in the language learning. It is predominantly implemented that involves the ELT subject content to teach in the module. It requires a specific ELT teacher development and 
program in the University of Benghazi. The contributions illustrate how knowledge of teaching ELT in the quality of education courses in English implementation (Lopriore, 2020).

ELT defined evaluation as the "systematic collection and analysis of all relevant information necessary to promote the improvement of a curriculum, and assesses its effectiveness and quality, as well as the participants' attitudes within the context of the particular institution involved". There are different interpretations of the term effectiveness. It considers effectiveness as something that has its own criteria and can be measured or assessed from the aspect of qualities and achievements. The effectiveness in education and teaching program is concerned with how far a course or activity has brought about the intended result pertaining to the acquisition of professional knowledge and skills expected of a teacher (Turan, \& Akdag-Cimen, 2020). In reality ELT is one of the rapid and dynamic in the area of development in modern linguistics. It influences the area of linguistics to include the teaching method of foreign languages, translation and other discipline of linguistics as a whole. It indicates the guidelines in the evaluation and the use of ELT in different aspect of teaching. It assesses and evaluates the ELT approach in the influence of education (Kogan, Zakharov, Popova, \& Almazova, 2020, July).

Therefore, the need of curriculum evaluation is essential for better improvement of the faculty of education in the university. It defines the evaluation and curriculum process that will gauge and attempt to the effectiveness and value of the educational activity in the ELT program. Evaluating a program effectiveness in absolute terms and/or assessing its quality against that of comparable programs. Program evaluation not only provides useful information to insiders on how the current work can be improved but also offers accountability to outside stakeholders. It discovers whether the curriculum designed, developed, and implemented is producing or can produce desired results. The strengths and weaknesses of the curriculum before implementation and the effectiveness can be highlighted through evaluation. The systematic and continuous evaluation of a program is significant for its improvement, which ultimately leads to the need for curriculum evaluation. It becomes a driving force in the effect of evaluation, implementation, and planning in ELT classroom essential and implication (Farrell, \& Jacobs, 2020).

\section{Research Questions}

1) What aspects of the English Language Teaching (ELT) program should be maintained and improved based on Peacock's Model of Evaluation?

2) How do the aspects of the English Language Teaching (ELT) program should be maintained and improved based on the Peacock's Model of Evaluation?

3) Is there a significant difference on the English Language Teaching (ELT) program that should be maintained and improved based on Peacock's Model of Evaluation as observed by the respondents? 


\subsection{Hypothesis}

There is a significant difference on the English Language Teaching (ELT) program that should be maintained and improved based on Peacock's Model of Evaluation as observed by the respondents.

\section{Concept of the Study}

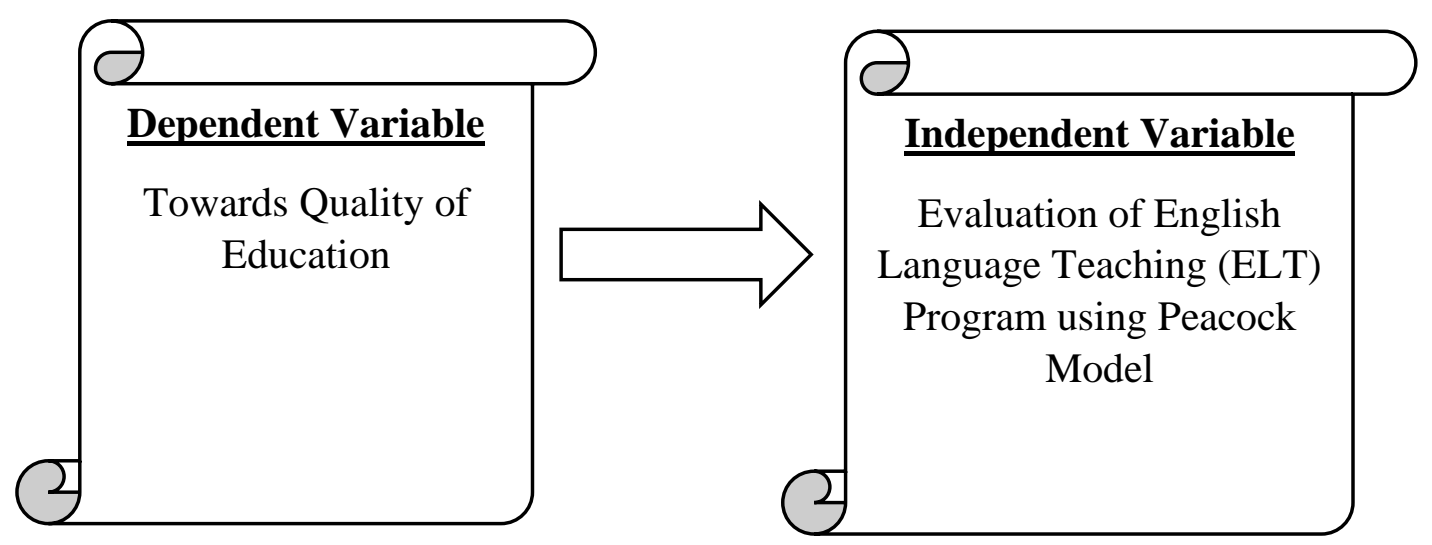

Figure 1: The flow of the study which is the dependent and independent variables

\subsection{Theoretical Lens}

This study is anchored on the Communication Theory Perspective in the English Language Teaching (ELT) that focuses on student and teacher's interaction in EFL classroom as cited by Weizheng (2019). The EFL teaching highlights the learners' cultivation and communicative competence because the English language purpose of learning is to target the language use to communicate among the learners. Many students in a non-native English-speaking countries cannot express themselves in English fluently even they have studied the English language. Although rules and guidelines in English are taught in all their curriculum and have mastered abundant English knowledge, enough grammar, and vocabulary which resulted to lack of interaction besides natural language and classroom teaching. Classroom is effective ELT key interaction which is important in promotion and strategy in English language learning. The theory explores the interaction between student and teacher in their ELT classroom on the communication, accommodation theory, and perspective. The theory provides teachers to use the strategy and communication accommodation to develop interaction in ELT class, provides answer to various strategies in ELT classroom for student and teacher interaction to include the ability to interpret, approximation, interpersonal control, and emotional expression as the basic strategies in the ELT theory.

\subsection{Research Method}

The quantitative and qualitative descriptive research design and method is utilized in the study because it is appropriate in the analysis and evaluation of the English Language 
Teaching (ELT) program of the Faculty of Education, University of Benghazi using the Peacock Model of evaluation toward quality education.

Qualitative descriptive design consists of different approaches in gathering the collection of data to help in the use of the provision, interpretation, and context description of an educational phenomena. Thematic analysis and content analysis in the approach of qualitative research are commonly used in different areas of research discipline. It addresses the gap and differences of knowledge and similarities in the data analysis and final product. It anticipates and understands the improved knowledge of the development theme in the quality content analysis of the study and supports the thematic analysis requirement of the study in terms of quality, findings and trustworthiness (Vaismoradi, \& Snelgrove, 2019, September).

Quantitative descriptive design describes the validation and development of the instruments which quantifies the discourse move of the researchers from observation to the final output of the data. It conceptualizes the tools and epistemic result for better discussion of the study. It describes the coding scheme through the Likert scale in the validation of the data process and development (Kranzfelder, et al., 2019).

\subsection{Participants of the Study}

The study comprised seventeen (17) alumni of the Faculty of Education, English Department, University of Benghazi as these participants had experienced the evaluation of the English Language Teaching program to be maintained and to be improved in the Faculty of Education.

\subsection{Sampling Technique}

The research employs purposive sampling because it is non-probability which is known as judgmental, subjective and selective sampling. It is a sampling technique that relies on judgement in choosing the population of the study. It provides systematic synthesis in both qualitative and quantitative evidence in the data to undermine ability to perform and analyze the population and data of the study. It performs the manageable achievement of data. It provides the development and data to be described in the application of the framework sampling (Ames, Glenton, \& Lewin, 2019).

\subsection{Statistical Instrument}

Aspects of ELT Program that should be maintained and improved:

\section{Scale Descriptive Level Descriptive Interpretation}

4.20-5.00 Strongly Agree The aspect of ELT program is highly observed

3.40-4.19 Agree The aspect of ELT program is observed

2.60-3.39 Neutral The aspect of ELT program is limited

1.80-2.59 Disagree The aspect of ELT program is not observed

1.00-1.79 Strongly Disagree The aspect of ELT program is not observed at all 


\section{Result}

Table 1: Aspects of ELT Program that Should be Maintained and Improved

\begin{tabular}{|c|c|c|c|}
\hline Indicator & $\begin{array}{l}\text { Weighted } \\
\text { Mean }\end{array}$ & Interpretation & Ranking \\
\hline 1. Has good linkage between different courses. & 3.94 & Agree & 17 \\
\hline $\begin{array}{l}\text { 2. Avoids overlapping information between different } \\
\text { courses. }\end{array}$ & 3.35 & Neutral & 22 \\
\hline 3. Gave me adequate training in English. & 4.41 & Strongly Agree & 3.5 \\
\hline 4. Gave me adequate training in teaching skills. & 4.35 & Strongly Agree & 5.5 \\
\hline $\begin{array}{l}\text { 5. Gave me adequate training for the needs of the local } \\
\text { context (Libya). }\end{array}$ & 3.76 & Agree & 20.5 \\
\hline 6. Is up-to-date. & 4.12 & Agree & 13.5 \\
\hline $\begin{array}{l}\text { 7. Encouraged me to reflect on my past experiences as a } \\
\text { language learner. }\end{array}$ & 4.12 & Agree & 13.5 \\
\hline $\begin{array}{l}\text { 8. Encouraged me to be a reflective teacher (when I start } \\
\text { teaching). }\end{array}$ & 4.53 & Strongly Agree & 1.5 \\
\hline $\begin{array}{l}\text { 9. Promotes flexibility in using different teaching } \\
\text { practices for different situation }\end{array}$ & 4.24 & Strongly Agree & 8 \\
\hline $\begin{array}{l}\text { 10. Balances teacher-centered and student-centered } \\
\text { learning on its courses. }\end{array}$ & 3.82 & Agree & 19 \\
\hline 11. Taught me how to teach English. & 4.35 & Strongly Agree & 5.5 \\
\hline 12. Taught me how to evaluate myself as a teacher. & 4.53 & Strongly Agree & 1.5 \\
\hline 13. Taught classroom management skills. & 4.41 & Strongly Agree & 3.5 \\
\hline $\begin{array}{l}\text { 14. Taught me how to use foreign language teaching } \\
\text { materials. }\end{array}$ & 4.24 & Strongly Agree & 8 \\
\hline $\begin{array}{l}\text { 15. Taught me how to adapt foreign language teaching } \\
\text { materials. }\end{array}$ & 4.18 & Agree & 11.5 \\
\hline 16. Increased my powers of self-evaluation. & 4.24 & Strongly Agree & 8 \\
\hline $\begin{array}{l}\text { 17. Taught me foreign language testing and evaluation } \\
\text { skills. }\end{array}$ & 3.88 & Agree & 18 \\
\hline 18. Is relevant to my needs. & 4.18 & Agree & 11.5 \\
\hline $\begin{array}{l}\text { 19. Has a good balance between the teaching of English, } \\
\text { teaching skills, classroom management skills. }\end{array}$ & 4.06 & Agree & 15.5 \\
\hline 20. Prepared me to teach English in the classroom. & 4.24 & Strongly Agree & 8 \\
\hline 21. Met my needs. & 3.76 & Agree & 20.5 \\
\hline $\begin{array}{l}\text { 22. By the end of the programme, I will be ready to teach } \\
\text { English. }\end{array}$ & 4.06 & Agree & 15.5 \\
\hline Average Weighted Mean & 4.13 & Agree & \\
\hline Standard Deviation & 0.285 & & \\
\hline
\end{tabular}

Table 1 presents the weighted mean and the corresponding interpretation on the aspect of ELT program that should be maintained and should be improved.

As gleaned in the table, it reveals that rank 1 is shared by the two indicators which are "encouraged me to be a reflective teacher (when I start teaching)", and " taught me how to evaluate myself as a teacher", with weighted mean of 4.53 or Strongly Agree. This means that aspect of ELT program is highly observed. Rank 2 is also shared by the two indicators which are "gave me adequate training in English", and "taught classroom 
management skills", with weighted mean of 4.41 or Strongly Agree. This means that aspect of ELT program is highly observed. Rank 3 is likewise shared by the two indicators which are "gave me adequate training in teaching skills", and "taught me how to teach English, with weighted mean of 4.35 or Strongly Agree. This means that aspect of ELT program is highly observed. The least in rank is "avoids overlapping information between different courses", with weighted mean of 3.35 or Neutral which means that aspect of ELT program is limited. The overall AWM=4.13 or Agree which means that aspect of ELT program is observed.

Table 2: Significant Difference on the aspect of ELT Program as Observed by the Respondents

\begin{tabular}{|l|c|c|c|c|}
\hline Variable & $\begin{array}{c}\mathbf{t}- \\
\text { computed value }\end{array}$ & Comparison & $\begin{array}{c}\text { t- critical } \\
\text { value }\end{array}$ & Decision \\
\hline $\begin{array}{l}\text { Aspect of ELT program as } \\
\text { observed by the respondents. }\end{array}$ & 59.553 & $>$ & 2.120 & Rejected \\
\hline Significant at 0.05 level with $\mathrm{df}=16$ & \multicolumn{3}{|l}{} \\
\hline
\end{tabular}

Table 2 presents the significant difference on the aspect of ELT program as observed by the respondents.

As observed in the table, it reveals that $t$ computed value is 59.553 which is greater than the $t$ critical value of 2.120 with a significant level of 0.05 , df of 16 . The decision is rejected and the alternative is accepted. Therefore, it is safe to say that there is significant difference on the English Language Teaching (ELT) program that should be maintained and improved based on Peacock's Model of Evaluation as observed by the respondents.

Table 3: Themes and Core Ideas on the Aspect of ELT Program that Should be Maintained and Improved through Peacock Model

\begin{tabular}{|c|c|c|}
\hline $\begin{array}{l}\text { Themes } \\
\text { (Peacock Model) }\end{array}$ & $\begin{array}{c}\text { Frequency of } \\
\text { Responses }\end{array}$ & Core Ideas \\
\hline 1. Participation & $\begin{array}{l}\text { Variant } \\
\text { General } \\
\text { General } \\
\text { Variant }\end{array}$ & $\begin{array}{l}>\text { flexibility in different teaching practices and situations } \\
>\text { evaluate myself as a teacher } \\
>\text { classroom management skills } \\
>\text { relevant to my needs }\end{array}$ \\
\hline 2. Experimentation & $\begin{array}{l}\text { General } \\
\text { Variant } \\
\text { Typical } \\
\text { Typical }\end{array}$ & $\begin{array}{l}>\text { adequate training in teaching skills } \\
>\text { adequate training for the needs of the local context } \\
>\text { teacher-centered and student-centered learning } \\
>\text { powers of self-evaluation }\end{array}$ \\
\hline 3. Application & $\begin{array}{l}\text { Typical } \\
\text { Variant } \\
\text { Typical } \\
\text { Variant } \\
\text { Typical }\end{array}$ & $\begin{array}{l}>\text { overlapping information on different courses } \\
>\text { up-to-date } \\
>\text { teaching of English } \\
>\text { meet needs of students } \\
>\text { ready to teach English }\end{array}$ \\
\hline 4. Cooperation & $\begin{array}{l}\text { Variant } \\
\text { General } \\
\text { Variant } \\
\text { Variant }\end{array}$ & $\begin{array}{l}>\text { reflect experiences as a language learner } \\
>\text { reflective teacher } \\
>\text { ELF testing and evaluation skills } \\
>\text { English teaching skills and classroom management }\end{array}$ \\
\hline 5. Knowledge & Typical & $>$ good linkage of different courses \\
\hline
\end{tabular}




\begin{tabular}{|l|l|l|}
\hline \hline & Typical & $>$ adequate training in English \\
& Typical & $>$ taught how to teach English \\
& Variant & $>$ use of EFL teaching materials \\
& Variant & $>$ adapt foreign language teaching materials \\
\hline
\end{tabular}

This presents the themes and core ideas on the aspect of ELT program that should be maintained and improved through the use of Peacock Model. It is the result of the focus group discussion among the respondents who are alumni of the Faculty of Education, University of Benghazi. Further, the thematic and core ideas are formulated through interview that has been conducted. Hence, the result of interviews is categorized according to the response and answer of the participants. The focus group discussion is classified into General which response and similarities of the participants belong to 50 percent and above, Typical of similarities when the responses belong to 25 to 29 percent, and Variant of similarities responses belong to 25 percent and below. The text verbatim is included to elaborate further the answers of the participants.

\title{
4.1 Participation
}

The participation of the English Language Teaching as based on the model provides the development and rapid expansion of students in their learning process. It implements the improvement of the teaching process in ELT. It improves the quality of learning and teaching of English Foreign Language or English Language that influence the participation of the professional teacher's development in the college context of the English Language Teaching curriculum (Zhiyong, Muthukrishnan, \& Sidhu, 2020). Generally, the participants observed that:

"promotes flexibility in using different teaching practices for different situations", (T1P7, P4)

\author{
"taught me how to evaluate myself as a teacher". (T1-P16, P2, P1) \\ "taught classroom management skills". (T1-P15, P2, P3) \\ "It is relevant to my needs". (T1-P7,P3,P4)
}

\subsection{Experimentation}

Experimentation in English Language Teaching investigates and designs the application of the motivational strategies for effective teaching, visionary techniques, and mental imagery to English language vocabulary and learning (Le-Thi, Dörnyei, \& PellicerSánchez, 2020). Typically, they said experimentation:

\footnotetext{
"gave me adequate training in teaching skills". (T2-P15, P4)

"gave me adequate training for the needs of the local context (Libya)". (T2-P6, P4)
} 
"balances teacher-centered and student-centered learning on its courses". (T-P9, P4)

"increased my powers of self-evaluation". (T2-P9, P2, P3)

\title{
4.3 Application
}

Application in the English Language Teaching is very essential. It teaches and provides the system of EFL in education that will be adopted in the school university and to ensure the continuity of the ELT module from the various purposes and approaches, techniques and methods, content and in form. It deepens the knowledge in the application and professional development skills appropriate to the principle of teaching for productive and effective language and teaching skills (Sherov, 2020). Typically, the participants suggest to:

\author{
"avoid overlapping information between different courses". (T3-P8, P5, P1) \\ "upgrade the application and is up-to-date". (T3-P7, P6) \\ "prepare me to teach English in the classroom". (T3-P9, P4, P2) \\ "provides application that meets my needs". (T3-P7, P5) \\ "by the end of the programme, I will be ready to teach English". (T3-P9, P1, P3)
}

\subsection{Cooperation}

Cooperation in the English Language Teaching provides knowledge and gain various form of cooperation to shape and take the level of facilitation in the learning perspective and achievement. It analyses the school system in the work of the educational system in English language. It entails challenges and benefits related to ELT. It provides support in the school system and management on the development of the professional provision to time and adequate planning. Flexible cooperation is a policy in education that is given emphasis in understanding the importance and condition of a standard responsible lecturers (Paulsrud, \& Nilholm, 2020). The participants say:

\footnotetext{
"encouraged me to reflect on my past experiences as a language learner". (T4-P7, P4, P2)

"encouraged me to be a reflective teacher (when I start teaching)". (T4-P16, P5)

"taught me foreign language testing and evaluation skills". (T4-P6, P5, P3)

"has a good balance between the teaching of: English, teaching skills, classroom management". (T4-P7, P6, P1)
} 


\title{
4.5 Knowledge
}

Knowledge is very essential in teaching English language because it provides a method for lecturers. Sharing experiences and knowledge will provide prospective English teachers the mastery of the lesson. Typically, the participants emphasized:

\author{
"knowledge has good linkage between different courses". (T5-P8, P1, P5) \\ "it gives adequate training in English". (T5-P9, P3, P1) \\ "it teaches how to teach English", (T5-P9, P5, P2) \\ "it teaches how to use foreign language teaching materials". (T5, P7, P1, P3) \\ "it teachers how to adapt foreign language teaching materials". (T5-P7, P4)
}

\section{Discussion}

The aspects of the English Language Teaching (ELT) can be improved or can be maintained in the various educational institutions. English language lecturers who are required to teach in the English module need to have sufficient knowledge in English curriculum because it helps in the variation and understanding of the various classroom task and engagement that identify the feature of the language and subject disciplinary discourses to draw the metalanguage in a meaningful way to the learning perspective of students. It develops the need to understand the knowledge of the lecturers in the ELT. It supports and collaborate increasingly the ELT subject area (Schleppegrell, 2020). Hence, it shows that ELT lecturers are encouraged to a reflective teacher when they teach ELT. It provides reflective practice and significance on widely recognized in both language and general education. It promotes and utilizes how technology examines the powerful tool of teachers in different educational English language contexts. It provides the language lecturers in the practical implication of the promotion of ELT (Yuan, Mak, \& Yang, 2020). On the other hand, it shows that there is adequate training in English because most of the lecturers are expert in teaching English due to their qualification and specialization for better learning process to non-native English country. It also provides adequate and necessary training skills of teaching and taught the proper manner of English language especially on classroom management. It provides the measure and performance of English lecturers in their level of competency. It involves challenges in the innovation of technical teaching in the Higher Education Institutions. It also examines the profile of respondents as to their level of performance and skills in teaching English as a Foreign Language (Mallillin, \& Mallillin, 2019).

On the other hand, in terms of participation on the aspect of English Language Teaching under the Peacock Model, it shows that participants promote flexibility in various teaching practices and various ELT situation. Flexible promotion of ELT plays 
and develops a vital role in the need and analysis of English as a powerful tool to design and help lecturers in the university and school colleges in the learners' target needs. It analyses the learner's type and learning need in the development of materials in the English academic syllabus and course (Menggo, Suastra, Budiarsa, Padmadewi, 2019). Consequently, participation in Peacock model shows to evaluate and teach teachers accordingly. The lecturers are expert in their major field of specialization in the Faculty of Education. Their evaluation reveals their performance as lecturers. Negative and positive evaluation will form part of the improvement for good, better, and best. Evaluation on lecturers is always available that will provide efficient and effective if not best for return of learning. It provides great lexical coverage on lecturers perception in a useful criteria of evaluation (Sun, Wei, \& Young, 2020). Nevertheless, it teaches the lecturers on the proper classroom management skills which is vital and essential in the learning process. It portrays the school multilateral in the perfect generation of quality education where students are to be taught inside the classroom for better learning which is challenging and very complicated due to the behavior and attitude of students inside the classroom. Lecturers are facing various issues in the process of teaching and communication where it requires proper and useful strategies to handle easily the learners as part of the management skills. Management skills in the classroom demonstrate the vital and effective strategies that focus on the principles of classroom management in the modern education (Babadjanova, 2020). Nonetheless, it also provides relevant needs among the lecturers in English Language Teaching due to the need of students in their learning process. It is very timely at present because education is a continuous process where skills need to be improved and to be upgraded for quality education.

Moreover, in the aspect of experimentation in the English Language Teaching shows adequate training in teaching skills which means experience of the module lecturers in English. They discover various techniques in the teaching process because of their personal and professional development. It devotes on the pedagogical experiences of the implementation and possibilities of the improved process of lecturers preparation in the pedagogical universities for development and innovation in strengthening the programs of ELT (Jabborov, 2020). This has been proven by the study of Jabbarova (2020) in a published proficiency of foreign language as one of the determined and significant leading facilities in the success of English professional lecturers. The vital task of English Language Teaching is oriented professionally in the lexical competence of teaching. Lecturers can focus on the process of learning and devote time in the communicative and English formation competency. Hence, the experiment will provide adequate training to the need of the local context of teaching and learning. English is a foreign language among the learners, teaching process must be based on the need in English language of learning. The purpose of teaching is to enhance students in their learning process. It examines the mindset and value of intrinsic self-efficacy and self-regulated learning in ELT for English learning language achievement (Bai, \& Wang, 2020). Hence, it balances the learning of both student and teacher centered in the ELT learning and courses. It 
explores the various challenges on the implementation of student-centered and teachercentered facilitator pedagogy on the influences of the learning and understanding the teacher culture and background, challenges, and discomfort faced in moving the process of student and teacher-centered position, and in creating self-reflexivity to merge in the new learning process in ELT (Nuñez Enriquez, \& Oliver, 2020). It also increases the power of self-evaluation of lecturers. It utilizes the model of implementing and developing strategies in ESL classroom (Raza, 2020).

Nonetheless, in the aspect of English Language Teaching in application is vital which shows to avoid the overlapping of information in various courses in the Faculty of Education. This needs to be reviewed for proper implementation and improvement. There is a need to innovate the overlapping information to ensure sustainable and success of ELT curriculum (Galloway, \& Numajiri, 2020). This can be done through innovation of various domain of learning in ELT. This will help in the learning process of students where it is designed for students to explore their knowledge and in-depth learning in the English language based on their needs as to the domain of cognitive, affective and psychomotor which is applicable in their learning process (Mallillin, 2020). Moreover, there is a need to upgrade the application of ELT and must be updated from time to time because teaching process is a continuous process. It encourages the practice and thinking of the education brought to various changes in terms of technology, resources and application (Ahmad, et al., 2019, February). On the other hand, the application helps to prepare in the classroom teaching process. This depends on the need of ELT lesson and need of student in their learning process in English language where the process will lead to the need of the English language learners. This will also lead to the readiness of lecturers in dealing with students. It is a growing trend in the English Language Teaching that will give quality teaching in affected English learners (Aguilar-Pérez, \& Arnó-Macià, 2020).

Furthermore, in the aspect of cooperation in English Language Teaching shows to encourage on the reflection of the English lecturers in their past experiences (Mallillin, \& Villareal, 2016). It provides language learning performance on the learners' belief, motivation, and anxiety in the continuous effort and learning predicting outcome. It provides motivation in the English learning on the promotion of self-regulation and learning motivation (Wang, \& Zhan, 2020). It also encourages the English lecturers to be a reflective teacher on the process of teaching. Reflective teachers are those lecturers that constrain the learners and lecturers demand in the implementation of English instruction that reflect the appropriate practice and adjustment in the English teacher process. It is a philosophy of principles, practices, and theories for action of responsibility in a systematic and combined reflection of the professional growth in effective English Language Teaching (Farrell, 2020). It shows also the participants are being taught on the evaluation and skills in the language testing as part of the process in the ELT. It is an assessment and connected language learning skills in accountable system in the English learning assessment and challenges in the self-regulating learning on the focus teacher expectation (Vattøy, 2020). Lastly, there is a good balance between teaching of English 
skills, and classroom management. It highlights the building between the teaching skills and classroom management that will be given emphasis which is a challenge among the lecturers in their well-being and priority (Ford, et al., 2019).

Lastly, in the aspect of English Language Teaching as to knowledge shows good linkage between different courses. Linkage of different courses in ELT provides details in English language in attending the struggle courses and challenges of the instruction in English language. It regulates the English learning and academics that contribute to the learning process of students. It views the English and information knowledge in recognizing the interactive process of students in various information and sources to enhance the usage of English in academic learning (Gan, Hu, Wang, Nang, \& An, 2020). Hence, it also provides and gives adequate training among the participants. Training in the skills of ELT improves the knowledge in the teaching pedagogy of English language lecturers. Training and skills in ELT improve the teaching language atmosphere and performs related testing activities for the English language lecturers. It provides readiness and performs the ability of the English teachers in determining the quality of English lecturers (Sultana, 2019). It also provides proper teaching management of English among the learners, especially on the proper use of foreign language and other English teaching materials where it provides teachers to adapt the foreign language and teaching materials. It improves the knowledge of English learning to fulfill the objectives of the English language learning. It motivates English learning inside the classroom setting which is beneficial to the progress of learning among students (Namaziandost, Neisi, Kheryadi, \& Nasri, 2019).

\section{Conclusion}

In the light of the findings and results of the analysis of the study. The following conclusions are drawn.

1) In the aspects of ELT program that should be maintained and should be improved, it shows that participants are encouraged to be a reflective teacher when they start teaching and taught to evaluate themselves which is vital and important in ELT profession in the Faculty of Education and in the study of English as a Foreign Language.

2) It shows to promote flexibility in using different teaching practices in different situation and classroom management skills in terms of participation.

3) It shows that there is adequate training and teaching skills and balances of teachercentered and student-centered learning on its courses in ELT in terms of experimentation.

4) It shows to avoid overlapping information between different courses and are ready to teach ELT of the program in the university in terms of application.

5) It shows that participants are encouraged to reflect on their past experiences as a language- learners and are encouraged to be a reflective teacher in their teaching process in terms of cooperation. 
6) It shows that there is a good linkage on various courses in ELT and give adequate training English in terms of knowledge.

\section{Recommendation}

In the light of the results and findings of the conclusions. The following recommendations are formulated.

1) There is a need to review the curriculum in the aspect of ELT program in the Faculty of Education because there is an overlapping information between different courses. Curriculum and program in ELT must be given emphasis based on the needs of the learners.

2) Classroom and management skills must be taught prior to teaching the ELT. This is important among the ELT lecturers for them to be guided on the rules and policies of the modules and subjects which are relevant to the needs of the lecturers in the area of participation.

3) There must be an adequate training among ELT lecturers for them to be guided on the local context of teaching based on the need of the learners. They need to increase their power and self-evaluation in ELT in the area of experimentation.

4) There is a need to upgrade and update knowledge in the ELT program to be competent in teaching. This is in preparation of teaching English in the classroom to meet the expectation and standard of ELT program in the Faculty of Education in the area of application.

5) There is a need to be taught in the foreign language testing and evaluation skills which is vital to ELT program because it balances the teaching of English skills and classroom management skills in the area of cooperation.

6) There is a need to specialize in teaching English so that foreign language can be delivered accordingly to include the use and adaption of the foreign English teaching materials in the ELT program and curriculum in the area of knowledge.

\section{Acknowledgements}

The authors wish to acknowledge those who are behind the success of this research, especially on the in-depth collaboration of the authors. Likewise, express their thanks to the alumni of the Faculty of Education, English Department, University of Benghazi, Libya for their cooperation in the focus group discussion and in answering the questionnaire objectively.

\section{Conflict of Interest Statement}

The authors declare no conflict of interests.

\section{About the Authors}

Dr. Regilito D. Laurel is an Assistant Professor at the Faculty of Education, English Department University of Benghazi, Libya. He teaches Research Methodology, Basics of 
Curriculum and Syllabus Design, Introduction to Education, School Administration and Supervision and Campus Journalism. He finished his Bachelor of Arts (AB) major in English Literature (cum laude), his Master's Degree in School Administration and Supervision (With Academic Distinction), and his Doctor of Philosophy (Ph.D.) in Development Education in the Philippines. He used to be the English coordinator and school paper adviser in the Division of Caloocan in the Philippines. He taught English in the Philippines, China and Libya. Dr. Laurel has been awarded as Most Outstanding Teacher. A recognition conferred to him by the United Federation of Filipino-American Educators (UNIFFIED) in August 2019. At present, he is the Research coordinator of the English department, Faculty of Education, University of Benghazi and has been working as Volunteer Acting Principal of Philippine Centennial Academy International (PCAI) in Benghazi since 2011. Further, he is the secretary of the Overseas Filipino Workers Organization in Benghazi $(O F W O-B)$. His research interests include continuing professional development, curriculum innovation, TESOL, ELT, Teaching Methodology, and Action Research on Education \& ELT.

Dr. Annabelle C. Belting is an English language teacher and an international speaker and trainer having conducted seminars and workshops in countries where she taught. She is a certified accreditor in the Philippines, having been trained by the Philippine Association of Colleges and Universities - Commission on Accreditation (PACUCOA) to accredit student services and outreach community programs. Dr. Belting was also an internal quality assurance auditor and coordinator of the English language department at the Bahrain Training Institute in Bahrain. Dr. Belting finished her Bachelor in Secondary Education majoring in English in the Philippines, Post Graduate Diploma in Second Language Teaching and Master in Applied Linguistics in New Zealand under the New Zealand Official Development Assistance (NZODA) scholarship program and her Doctor of Philosophy in the Philippines. Dr. Belting taught English in the Philippines, Thailand, Indonesia, Bahrain, and Libya. Her research interests are mainly on language testing, teaching English as a foreign / second language, program and syllabus design, and professional development for English teachers. Throughout her teaching career, she headed various initiatives including English camps and immersions in Thailand and Philippines. She was also responsible in signing linkages related to English programs and projects. Dr. Belting is currently teaching at the Faculty of Education at the University of Benghazi, Libya handling EFL teaching and professional courses. She also gives trainings and workshops on quality assurance (QA) and is currently the QA coordinator of the English department at the Faculty of Education, University of Benghazi, Libya.

Ennaji Omran Almansouri is an EFL lecturer at the Education Faculty, Benghazi University. He holds a BA in Translation and a Master's degree in Applied Linguistics from the Faculty of Arts, University of Benghazi. He teaches the courses of translation, semantics and the skills of reading and writing. Currently, he holds the position of the English Department Head, prior to that, he was the Quality Assurance (QA) Coordinator at the Faculty (2013-2019). His research area of interest is the development of English teaching methods and strategies for Arab learners. He is interested in using translation 
(NOT Grammar-Translation Method) from native language into target language to improve writing skills and vice versa to improve reading skills.

\section{References}

Aguilar-Pérez, M., \& Arnó-Macià, E. (2020). "He's a Good Lecturer in Any Language": Shifting from L1 to English and Implications for EMI Training. In Teacher training for English-medium instruction in higher education (pp. 153-178). IGI Global.

Ahmad, M. K., Adnan, A. H. M., Azamri, N. M., Idris, K. B., Norafand, N. N., \& Ishak, N. I. (2019, February). Education 4.0 technologies for English language teaching and learning in the Malaysian context. In Proceedings of the International Invention, Innovative \& Creative (InIIC) Conference, Series (pp. 6-16).

Ames, H., Glenton, C., \& Lewin, S. (2019). Purposive sampling in a qualitative evidence synthesis: A worked example from a synthesis on parental perceptions of vaccination communication. BMC medical research methodology, 19(1), 1-9.

Babadjanova, N. (2020). Effective classroom management techniques for curriculum of 21st century. Science and Education, 1(7).

Chen, H. (2020). A Contrastive Analysis of Classroom-Based Language Assessments. English Language Teaching, 13(5), 110-114.

Farrell, T. S. (2020). Professional development through reflective practice for Englishmedium instruction (EMI) teachers. International Journal of Bilingual Education and Bilingualism, 23(3), 277-286.

Farrell, T. S., \& Jacobs, G. M. (2020). Essentials for successful English language teaching. Bloomsbury Publishing.

Ford, T., Hayes, R., Byford, S., Edwards, V., Fletcher, M., Logan, S., ... \& Ukoumunne, O. C. (2019). The effectiveness and cost-effectiveness of the Incredible Years ${ }^{\circledR}$ Teacher Classroom Management programme in primary school children: results of the STARS cluster randomised controlled trial. Psychological medicine, 49(5), 828-842.

Galloway, N., \& Numajiri, T. (2020). Global Englishes Language Teaching: Bottom-up Curriculum Implementation. TESOL Quarterly, 54(1), 118-145.

Gan, Z., Hu, G., Wang, W., Nang, H., \& An, Z. (2020). Feedback behaviour and preference in university academic English courses: associations with English language selfefficacy. Assessment \& Evaluation in Higher Education, 1-16.

Jabari, N. A. (2020). New learning styles models in adaptive educational process. Jurnal Pendidikan Sains, 8(1).

Jabbarova, A. (2020). Effective 21st Century English Teaching. Архив Научных Публикаций JSPI, 1-4.

Jabbarova, A. (2020). Teaching English for Professionally Oriented Students. Архив Научных Публикаций JSPI. 
Jabborov, U. (2020). Modeling the Pedagogical Experience of England as a Factor of Improving the Quality of Training Future Teachers. Архив Научных Публикаций JSPI.

Kogan, M., Zakharov, V., Popova, N., \& Almazova, N. (2020, July). The Impact of Corpus Linguistics on Language Teaching in Russia's Educational Context: Systematic Literature Review. In International Conference on Human-Computer Interaction (pp. 339-355). Springer, Cham.

Kranzfelder, P., Bankers-Fulbright, J. L., García-Ojeda, M. E., Melloy, M., Mohammed, S., \& Warfa, A. R. M. (2019). The Classroom Discourse Observation Protocol (CDOP): A quantitative method for characterizing teacher discourse moves in undergraduate STEM learning environments. PloS one, 14(7), e0219019.

Le-Thi, D., Dörnyei, Z., \& Pellicer-Sánchez, A. (2020). Increasing the effectiveness of teaching L2 formulaic sequences through motivational strategies and mental imagery: A classroom experiment. Language Teaching Research, 1362168820913125.

Lopriore, L. (2020). Reframing teaching knowledge in Content and Language Integrated Learning (CLIL): a European perspective. Language Teaching Research, 24(1), 94104.

Mallillin, L. L. D. (2020). Different Domains in Learning and the Academic Performance of the Students. Journal of Educational System, 4(1), 1-11.

Mallillin, L. L. D., \& Mallillin, J. B. (2019). Competency Skills and Performance Level of Faculties in the Higher Education Institution (HEI). European Journal of Education Studies.

Mallillin, L. L. D., \& Villareal, I. P. (2016). Exposure to English and level of English proficiency of international foundation programme students in gulf college. International Journal of Advanced Research in Management and Social Sciences, 5(12), 80-98.

Matkasimova, D. B. K., \& Makhmudov, K. S. U. (2020). Importance of interactive methods in the English language grammar teaching. Science and Education, 1(Special Issue 2).

Menggo, S., Suastra, I., Budiarsa, M., \& Padmadewi, N. N. (2019). Needs Analysis of Academic-English Speaking Material in Promoting 21st Century Skills. International Journal of Instruction, 12(2), 739-754.

Namaziandost, E., Neisi, L., Kheryadi, \& Nasri, M. (2019). Enhancing oral proficiency through cooperative learning among intermediate EFL learners: English learning motivation in focus. Cogent Education, 6(1), 1683933.

Nuñez Enriquez, O., \& Oliver, K. L. (2020). 'The collision of two worlds': when a teachercentered facilitator meets a student-centered pedagogy. Sport, Education and Society, 1-12.

Paulsrud, D., \& Nilholm, C. (2020). Teaching for inclusion-a review of research on the cooperation between regular teachers and special educators in the work with 
students in need of special support. International Journal of Inclusive Education, 1-15.

Schleppegrell, M. J. (2020). The knowledge base for language teaching: What is the English to be taught as content?. Language Teaching Research, 24(1), 17-27.

Setiyadi, A. (2020). Teaching English as a foreign language.

Sherov, D. (2020). Succession Issues in Teaching English. Academic Research in Educational Sciences, (3).

Sultana, N. (2019). Language assessment literacy: An uncharted area for the English language teachers in Bangladesh. Language Testing in Asia, 9(1), 1-14.

Sun, C., Wei, L., \& Young, R. F. (2020). Measuring teacher cognition: Comparing Chinese EFL teachers' implicit and explicit attitudes toward English language teaching methods. Language Teaching Research, 1362168820903010.

Turan, Z., \& Akdag-Cimen, B. (2020). Flipped classroom in English language teaching: a systematic review. Computer Assisted Language Learning, 33(5-6), 590-606.

Vaismoradi, M., \& Snelgrove, S. (2019, September). Theme in qualitative content analysis and thematic analysis. In Forum Qualitative Sozialforschung/Forum: Qualitative Social Research (Vol. 20, No. 3).

Vattøy, K. D. (2020). Teachers' beliefs about feedback practice as related to student selfregulation, self-efficacy, and language skills in teaching English as a foreign language. Studies in Educational Evaluation, 64, 100828.

Wang, W., \& Zhan, J. (2020). The relationship between English language learner characteristics and online self-regulation: A structural equation modeling approach. Sustainability, 12(7), 3009.

Weizheng, Z. (2019). Teacher-Student Interaction in EFL Classroom in China: Communication Accommodation Theory Perspective. English Language Teaching, 12(12), 99-111.

Yuan, R., Mak, P., \& Yang, M. (2020). 'We teach, we record, we edit, and we reflect': Engaging pre-service language teachers in video-based reflective practice. Language Teaching Research, 1362168820906281.

Zhiyong, S., Muthukrishnan, P., \& Sidhu, G. K. (2020). College English Language Teaching Reform and Key Factors Determining EFL Teachers' Professional Development. European Journal of Educational Research, 9(4), 1393-1404. 

to copy, distribute, transmit or adapt the article content, providing a proper, prominent and unambiguous attribution to the authors in a manner that makes clear that the materials are being reused under permission of a Creative Commons License. Views, opinions and conclusions expressed in this research article are views, opinions and conclusions of the author(s). Open Access Publishing Group and European Journal of Education Studies shall not be responsible or answerable for any loss, damage or liability caused in relation to/arising out of conflicts of interest, copyright violations and inappropriate or inaccurate use of any kind content related or integrated into the research work. All the published works are meeting the Open Access Publishing requirements and can be freely accessed, shared, modified, distributed and used in educational, commercial and non-commercial purposes under a Creative Commons Attribution 4.0 International License (CC BY 4.0). 